\title{
Colposcopy, biopsy, and cytology results in women with chlamydial cervicitis
}

\author{
E M C DUNLOP,* A GARNER, $\dagger$ S DAROUGAR, $\ddagger$ J D TREHARNE, \\ R M WOODLAND $\ddagger$ \\ From the *Diagnostic Clinics, Moorfields Eye Hospital and Institute of Ophthalmology, Judd Street; \\ the $\dagger$ Department of Pathology, Institute of Ophthalmology, Cayton Street; and the $\ddagger$ Section of Virology, \\ Institute of Ophthalmology, Judd Street, London
}

SUMMARY Colposcopy and biopsy were carried out at diagnosis and at follow up of 222 women. Of 322 cervical biopsy specimens taken, 174 were from women with chlamydial cervicitis (patients) and 48 from control women (both at diagnosis) and 100 from 76 patients and seven controls at follow up.

Of the 174 patients with chlamydial cervicitis, $158(91 \%)$ had erythema compared with 9/48 (19\%) controls, and $140(81 \%)$ had "follicles" and lumps compared with three $(6 \%)$ controls. The cervical polymorphonuclear leucocyte $(P M N L)$ count in a high power $(\times 1000)$ field $(H P F)$ was 85 in patients compared with 47/HPF in controls. Cervical ectopia was found in $154(89 \%)$ patients compared with $32(67 \%)$ controls. After treating the 174 patients, we found erythema in nine $(5 \%)$ and "follicles" in $16(9 \%)$; both conditions were disappearing.

Lymphocytic germinal follicles were found on histology in only $5 / 165$ patients compared with none in controls or in patients at follow up examination (after treatment for chlamydial cervicitis). Inclusions were found in 6/165 patients compared with none in controls or patients at follow up. Chlamydiae were found on electron microscopy in slides from seven out of 159 patients compared with none from controls or 81 subjects at follow up.

Estimating numbers of inflammatory cells and measuring vascularity showed diffuse increases in lymphocytes and plasma cells and increases in vascularity in both endocervical and exocervical tissue of patients with chlamydial cervicitis. These increases were lessened by treatment.

From 1962, women who attended the diagnostic clinics at Moorfields Eye Hospital or the Institute of Ophthalmology for examination because of possible genital infection with Chlamydia trachomatis have been examined with a colposcope, and the appearances have been recorded. In tissues infected by $C$ trachomatis, "follicles" that resembled the follicles seen in chlamydial conjunctivitis' were present in the columnar epithelium of the cervix, particularly near the marginal area. ${ }^{1-7}$ They were also seen in the rectal mucosa of the infected women ${ }^{589}$ and of $\operatorname{men}^{10}$ and also in the urethras of a few men. ${ }^{3}$ Follicles have been seen and confirmed histologically in the urethras of non-human primates infected experimentally with $C$ trachomatis. ${ }^{.1}$

Some workers have reported follicles on light microscopy of cervical biopsy material from patients

Address for reprints: Professor S Darougar, Section of Virology, Institute of Ophthalmology, Judd Street, London WC1H 9QS

Accepted for publication 2 April 1988

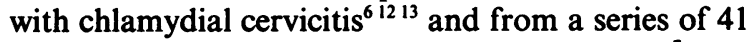
such patients and 41 controls, all with cervicitis.?

On electron microscopy, $C$ trachomatis has been found in inflamed cervical tissue not only from women with gonorrhoe ${ }^{12}$ but also from those without gonorrhoea ${ }^{13}$ as would be expected of a pathogen.

A high incidence of chlamydial infection in cervical dysplastic change has been reported..$^{14} 15$

Starting in 1967, specimens from the clinically most affected (columnar) area in each patient were taken routinely by us in studies of chlamydial genital infection. Accordingly, we now report the incidence of different findings on colposcopy and biopsy in 322 valid biopsy specimens obtained from patients before and, from some, after treatment for chlamydial cervicitis and from control subjects. We also report the results of examination of Ayre (Papanicolaou) smears.

\section{Patients and methods}

PATIENTS

Women admitted to this study attended the diagnostic 
clinics at either Moorfields Eye Hospital or the Institute of Ophthalmology. These are referral clinics for diagnosing and managing sexually transmitted diseases (STD) in patients attending Moorfields Eye Hospital. Referral as a patient or a sexual contact was because the patient herself or her consort or child was suspected of having STD, usually because of conjunctivitis. All the women were sexually active. None had clinical evidence of active genital herpes.

The 174 women with chlamydial cervicitis but not gonorrhoea (whose cervical, urethral, and anorectal smears and cultures gave negative results for Neisseria gonorrhoeae) were aged 14 to 43 (mean 24). The 48 controls, who had neither chlamydial nor gonoccoccal infection, were aged 19 to 52 (mean 27).

Of the 174 patients, $159(91 \%)$ were white, 141 $(81 \%)$ were white and British born, $13(8 \%)$ were black, and two (1\%) were Asian. Of the 48 controls, 42 $(88 \%)$ were white, $39(81 \%)$ were white and British born, and six (13\%) were black.

\section{METHODS}

These have been described previously. ${ }^{2-416}$ In particular, we examined and tested all patients using a Zeiss universal operating microscope arranged as a colposcope with an $100 \mathrm{~mm}$ objective at a magnification of $\times 25$. We recorded the cervical appearances in each patient's notes, and photographed them with a coupled camera. From patients seen in the past three years we took additional cervical mucus and urethral and rectal material for testing for local antibody to chlamydiae before taking material for other tests from those sites. We took triple swabs for culture for chlamydiae from the cervix (and the urethra and rectum), and triple cervical scrapes. In the early studies these tests had been single from each site, but triple tests increased the efficiency of tests for chlamydiae. ${ }^{17}$ After taking the cervical swabs we took a cytological (Ayre) smear from each patient. The cervical area showing most inflammatory change was recorded

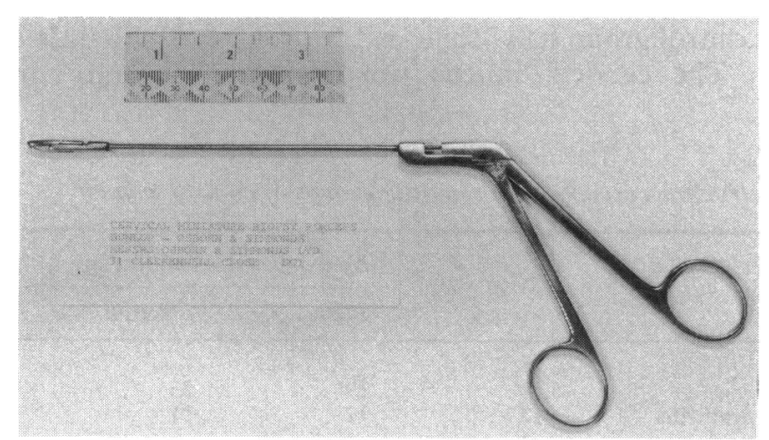

Fig 1 Dunlop-Osborn \& Simmonds cervical miniature biopsy forceps. photographically and, after the patient had given permission, a biopsy specimen was taken from it for light microscopy and another for electron microscopy. We used a Leech-Wilkinson biopsy forceps initially. To facilitate the collection of small specimens under colposcopic view from outpatients, however, this was replaced by a Storz biopsy punch and then by a miniature cervical biopsy forceps (fig 1). Finally, the biopsy site was photographed. We measured the incidence of each type of cell and the degree of vascularity in biopsy specimens roughly in tens on a simple scale of $0-30$.

\section{STATISTICAL ANALYSES}

We used the $\chi^{2}$ and Mann-Whitney tests to analyse our results.

\section{Results}

CLASSIFICATION OF PATIENTS AND CONTROLS We assessed 322 valid biopsy specimens and the related colposcopic findings for this study. The specimens were usually paired for light and electron microscopy. Specimens taken during diagnostic examinations were obtained from 222 subjects (patients and controls) and 100 follow up biopsies were carried out on 83 subjects (table 1).

Of the 174 biopsy specimens taken at diagnosis of patients with chlamydial cervicitis, 149 yielded $C$ trachomatis on culture. The remaining 25 did not yield chlamydiae, but contained local antibody to chlamydiae (table 2). In no case did electron microscopy give a positive result in the absence of a positive cervical culture result.

We classed 30 women as controls (table 3 ) because culture of material from the urethra, cervix, and rectum gave negative results for $C$ trachomatis on one or more occasions, as did tests for systemic and local antibody to chlamydiae. Twelve women also gave negative results, but were sexual contacts of men

Table 1 Numbers of subjects (patients with chlamydial cervicitis or controls) and biopsy specimens at diagnosis and follow up (after antichlamydial treatment)

\begin{tabular}{lll}
\hline Groups of subjects & $\begin{array}{l}\text { No of biopsy } \\
\text { specimens }\end{array}$ & $\begin{array}{l}\text { No of } \\
\text { subjects }\end{array}$ \\
\hline $\begin{array}{ll}\text { At diagnosis: } \\
\text { Patients }\end{array}$ & 174 & 174 \\
Controls & 48 & 48 \\
Total & 222 & 222 \\
At follow up: & 92 & 76 \\
Patients* & 8 & 7 \\
Controls & 100 & 83 \\
\hline Total & 8 & \\
\hline
\end{tabular}

*All with negative results to cervical cultures for Chlamydia trachomatis after antichlamydial treatment. 
24

Table 2 Microscopy of cervical biopsy specimens taken at diagnosis from 174 women with chlamydial cervicitis

\begin{tabular}{|c|c|c|c|}
\hline \multirow{2}{*}{$\begin{array}{l}\text { Cervical } \\
\text { test results }\end{array}$} & \multirow{2}{*}{$\begin{array}{l}\text { No of } \\
\text { biopsy } \\
\text { specimens }\end{array}$} & \multicolumn{2}{|c|}{$\begin{array}{l}\text { No examined } \\
\text { by microscopy }\end{array}$} \\
\hline & & Light & Electron \\
\hline \multirow{2}{*}{$\begin{array}{l}\text { Chlamydiae on culture } \\
\text { Local antibody to chlamydiae, } \\
\text { culture negative }\end{array}$} & 149 & 142 & 134 \\
\hline & 25 & 23 & 25 \\
\hline Total & 174 & 165 & 159 \\
\hline
\end{tabular}

suffering from gonorrhoea or non-gonococcal urethritis (NGU). A further six women also gave negative results, except that they had systemic antibody (IgG) to chlamydiae at a titre of $1 / 32$ or less. We added the last 18 subjects to the first control group to form an extended control group of 48 women.

\section{MICROSCOPY}

Table 4 shows that of the 92 follow up biopsy specimens of cervical material from patients who had had chlamydial cervicitis before treatment, we examined 89 (from 76 patients) by light microscopy and 80 (from 61 patients) by electron microscopy. Of the eight follow up specimens from control subjects, we examined seven by light microscopy and six by electron microscopy.

Of the overall total of 322 (diagnostic and follow up) biopsy specimens, 308 were examined by light and 287 by electron microscopy.

\section{COLPOSCOPY}

Table 5 shows that erythema of the columnar cervical epithelium (fig 2) was present at diagnostic examination in $158(91 \%)$ of the 174 patients with chlamydial cervicitis, in only six $(20 \%)$ of the 30 controls $\left(\chi^{2}=77 ; \mathrm{p}<0.001\right)$, and in nine $(19 \%)$ of the 48 in the extended control group $\left(\chi^{2}=100 ; p<0.001\right)$. Erythema particularly affected the columnar cervical epithelium generally and the periglandular areas (fig 2) but it did extend to the marginal area of the squamous epithelium where it caused capillary congestion. The erythema on columnar epithelium was commonly
Dunlop, Garner, Darougar, Treharne, Woodland

Table 4 Numbers of biopsy specimens examined by light and electron microscopy at follow up from patients and controls

\begin{tabular}{lccc}
\hline & \multicolumn{2}{l}{ No examined by microscopy } \\
\cline { 3 - 4 } & No & Light & Electron \\
\hline Patients* & 92 & 89 & 80 \\
Controls & 8 & 7 & 6 \\
Total & 100 & 96 & 86 \\
\hline
\end{tabular}

* All yielded negative cervical cultures for Chlamydia trachomatis after antichlamydial treatment.

Table 5 Colposcopic signs and cervical mucus at diagnosis of patients with chlamydial cervicitis and controls (figures are numbers (percentages) of subjects except where stated otherwise)

\begin{tabular}{|c|c|c|c|}
\hline Cervical signs & $\begin{array}{l}\text { Patients } \\
(n=174)\end{array}$ & $\begin{array}{l}\text { Controls } \\
(\mathrm{n}=30)\end{array}$ & $\begin{array}{l}\text { Extended } \\
\text { controls } \\
(\mathrm{n}=48)\end{array}$ \\
\hline $\begin{array}{l}\text { Erythema } \\
\text { No erythema }\end{array}$ & $\begin{array}{r}158(91) \\
16(9)\end{array}$ & $\begin{array}{r}6(20) \\
24(80)\end{array}$ & $\begin{array}{r}9(19) \\
39(81)\end{array}$ \\
\hline $\begin{array}{l}\text { "Follicles" } \\
\text { Lumps alone }\end{array}$ & $\begin{array}{r}109(63) \\
31(18)\end{array}$ & $\begin{array}{l}0 \\
0\end{array}$ & $\begin{array}{l}3(6) \\
0\end{array}$ \\
\hline $\begin{array}{l}\text { "Follicles" or } \\
\text { lumps } \\
\text { No "follicles" }\end{array}$ & $140(81)$ & 0 & $3(6)$ \\
\hline or lumps & $34(20)$ & $30(100)$ & $45(94)$ \\
\hline $\begin{array}{l}\text { Maximum PMNL } \\
\text { count/HPF }\end{array}$ & 85 & 43 & 47 \\
\hline Ectopia, "erosion" & $154(89)$ & $18(60)$ & $32(67)$ \\
\hline
\end{tabular}

PMNL = polymorphonuclear leucocytes.

$\mathrm{HPF}=$ high power $(\times 1000$ magnification $)$ field.

accompanied by varying degrees of local swelling, diffuse or forming "follicles" and lumps.

"Follicles" alone (fig 2) or with lumps that were confluent "follicles" (fig 3 ) or less defined thickenings (fig 4) were present in 109 women $(63 \%)$ and lumps alone in another $31(18 \%)$. Thus $140(81 \%)$ of the 174 women with chlamydial cervicitis had "follicles" or lumps, or both. None of the 30 controls had "follicles" or lumps, and only three $(6 \%)$ of the 48 in the extended control group had "follicles" $\left(\chi^{2}=62.1 ; p<0.001\right)$.

The cervical mucus was commonly cloudy or

Table 3 Numbers of biopsy specimens examined by light and electron microscopy from separate groups of control women

\begin{tabular}{lcccc}
\hline Biopsy results & \multicolumn{2}{c}{ No examined by microscopy } \\
\cline { 3 - 5 } No chlamydiae on culture, no local or systemic antibodies to chlamydiae, & $\begin{array}{l}\text { No of } \\
\text { women }\end{array}$ & Light & Electron \\
and negative results on light and electron microscopy & 30 & 29 & 25 \\
Negative but sexual contacts of men with gonorrhoea or non-gonococcal urethritis & 12 & 6 & 6 \\
Negative except systemic antibodies to chlamydiae & 6 & 6 & 47 \\
Total controls & 48 & 47 & 42 \\
\hline
\end{tabular}




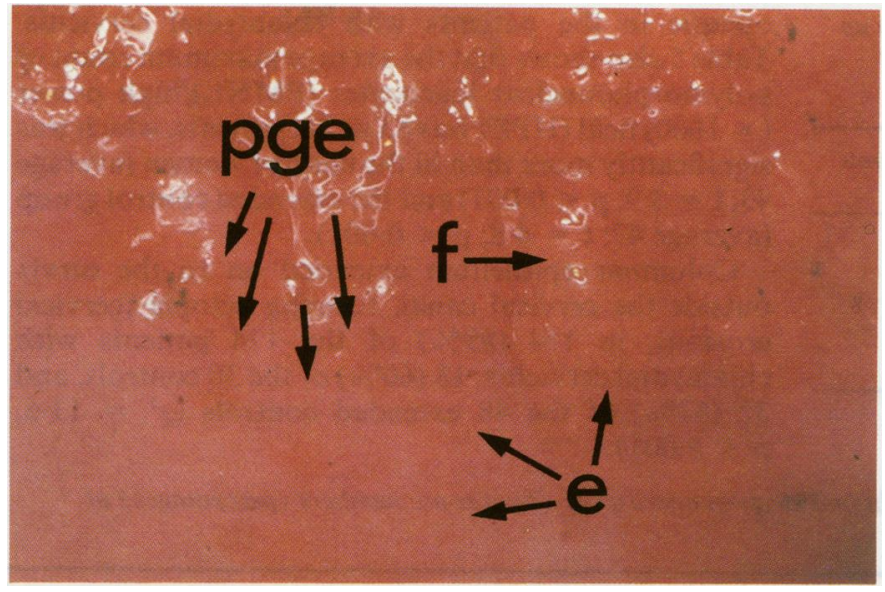

Fig 2 Chlamydial cervicitis showing general erythema $(e)$, periglandular erythema (pge), and "follicles" ( $f)$.

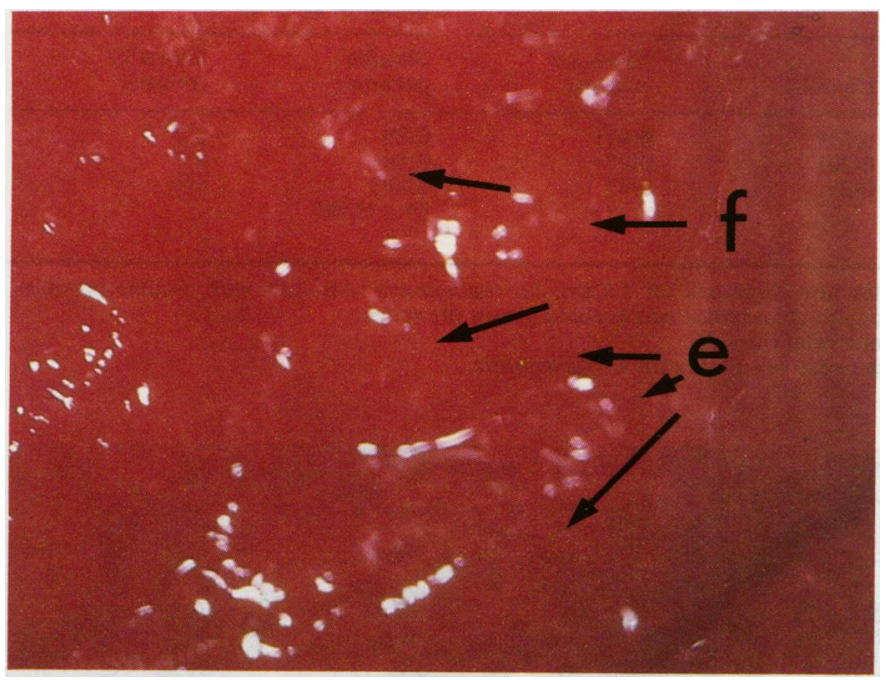

Fig 3 Chlamydial cervicitis showing erythema $(e)$ and confluent "follicles" $(f)$ forming a lump.

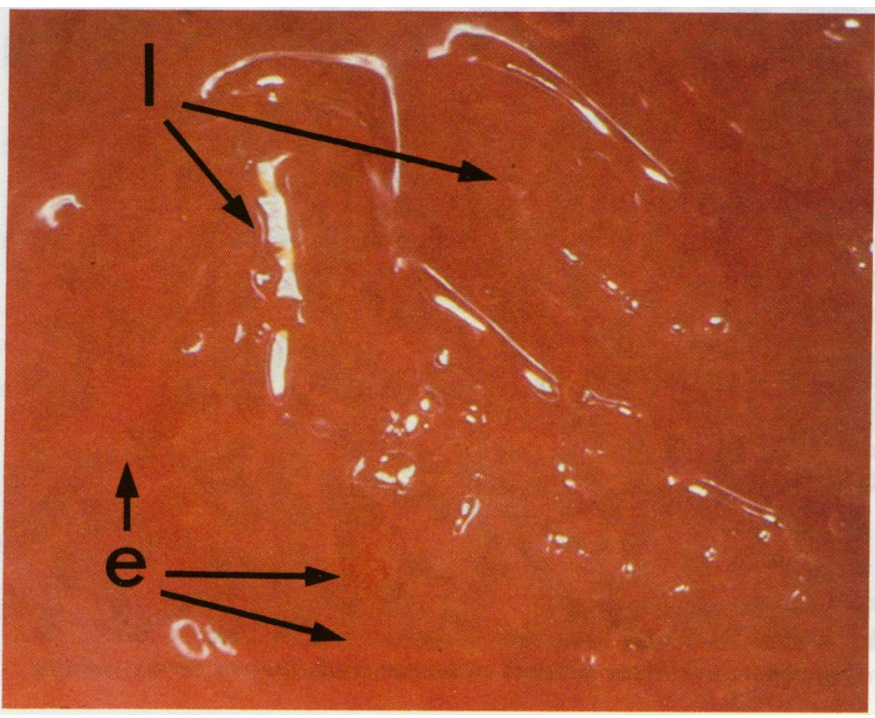

Fig 4 Chlamydial cervicitis showing erythema $(e)$ and large lumps $(l)$. 
Table 6 Colposcopic signs and cervical mucus at follow up biopsies (figures are numbers (percentages) of biopsy specimens except where otherwise stated)

\begin{tabular}{lcl}
\hline Cervical signs & $\begin{array}{l}\text { Treated patients } \\
(n=92)\end{array}$ & $\begin{array}{l}\text { Extended controls } \\
(n=8)\end{array}$ \\
\hline Erythema & $5(5)$ & 0 \\
No erythema & $87(95)$ & $8(100)$ \\
"Follicles" & $8(9)$ & 0 \\
No "follicles" & $84(91)$ & $8(100)$ \\
Maximum PMNL & 41 & 60 \\
count/HPF & &
\end{tabular}

PMNL = polymorphonuclear leucocytes.

$\mathrm{HPF}=$ high power $(\times 1000$ magnification $)$ field.
(1)

Table 7 Findings in biopsy specimens examined by light and electron microscopy (figures are numbers (percentages) of subjects)

\begin{tabular}{|c|c|c|c|c|c|}
\hline \multirow[b]{2}{*}{ Findings } & \multicolumn{3}{|l|}{ At diagnosis } & \multicolumn{2}{|l|}{ At follow up } \\
\hline & Patients & Controls & $\begin{array}{l}\text { Extended } \\
\text { controls }\end{array}$ & $\begin{array}{l}\text { Treated } \\
\text { patients }\end{array}$ & $\begin{array}{l}\text { Extended } \\
\text { controls }\end{array}$ \\
\hline $\begin{array}{l}\text { Lymphocytic germinal follicles } \\
\text { Inclusions } \\
\text { Chlamydiae on electron microscopy }\end{array}$ & $\begin{array}{l}5 / 165(3) \\
6 / 165(4) \\
7 / 159^{*}(4) \\
(+4 \mathrm{HSV}) \\
(+1 \mathrm{HPV})\end{array}$ & $\begin{array}{l}0 / 29 \dagger \\
0 / 29 \dagger \\
0 / 25\end{array}$ & $\begin{array}{l}0 / 47 \dagger \\
0 / 47 \dagger \\
0 / 42\end{array}$ & $\begin{array}{l}0 / 89 \\
0 / 89 \\
0 / 80 \ddagger \\
(+2 \text { HSV })\end{array}$ & $\begin{array}{l}0 / 7 \\
0 / 7 \\
0 / 6\end{array}$ \\
\hline
\end{tabular}

*One patient with local antibody to chlamydiae had particles not diagnostic of Chlamydia trachomatis. Another with similar particles, negative cervical culture for $C$ trachomatis, and no local antibody to chlamydiae was excluded from the series. tOne patient had cancer of cervix, electron microscopy result not valid (blood).

tOne patient had particles not diagnostic of $C$ trachomatis with negative cultures for $C$ trachomatis.

HSV $=$ herpes simplex virus.

$\mathrm{HPV}=$ human papillomavirus (wart virus).

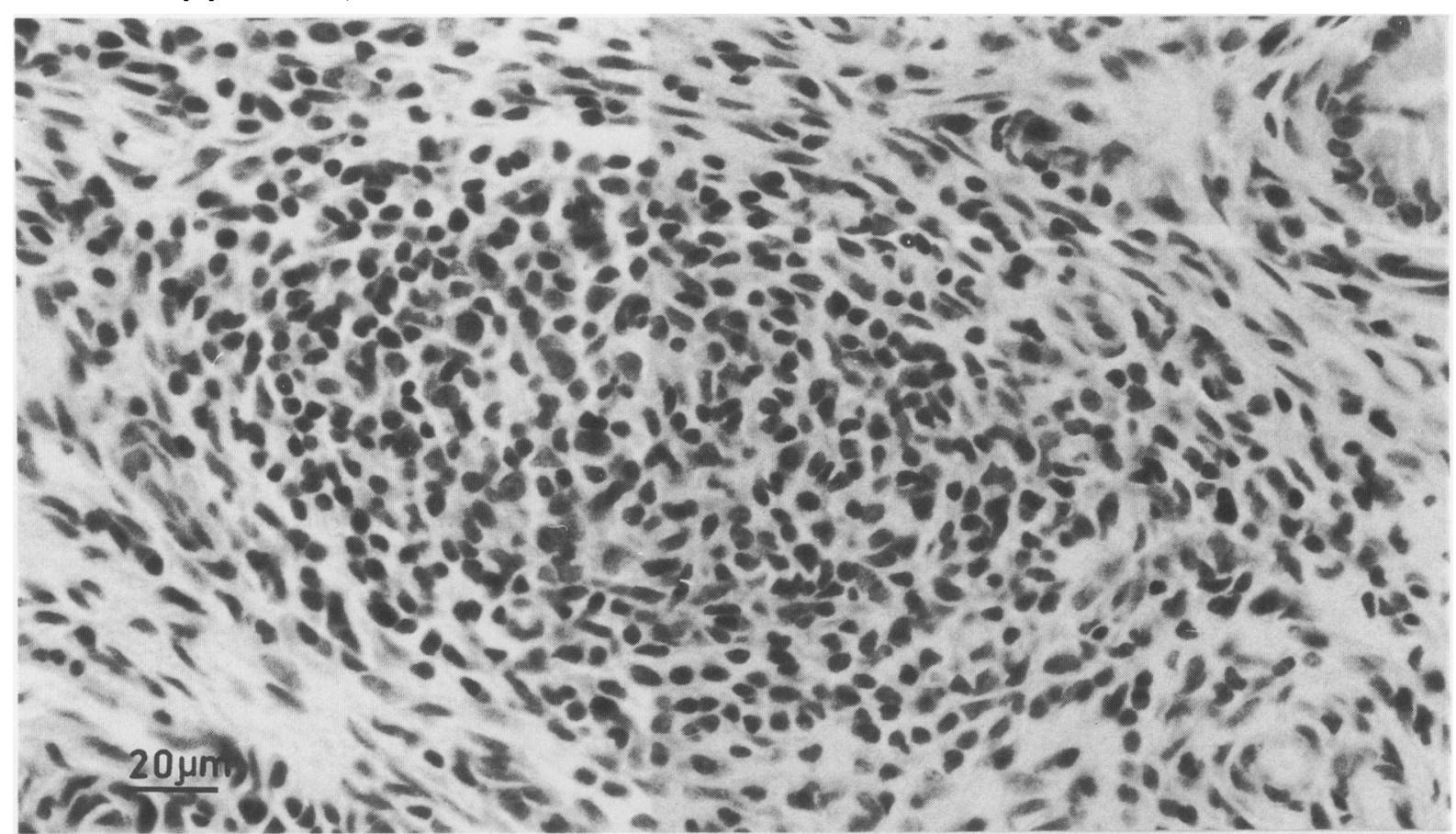

Fig 5 Lymphoid germinal follicle (with germinal centre) in connective tissue beneath columnar epithelium of cervix yielding Chlamydia trachomatis (haematoxylin and eosin).

opaque in the patients with chlamydial cervicitis. $(\times 1000)$ field $(H P F)$ was 85 in the patients, which was significantly more than in the control women (average $43 ; t=3.9 ; p<0.001$ ) and the extended control group 47; $t=4.8 ; p<0.001$ outside the cervical canal, forming ectopia (cervical erosion), in $154(89 \%)$ of the 174 patients with chlamydial cervicitis, $18(60 \%)$ of the 30 controls, and $32(67 \%)$ of the 48 extended controls $\left(\chi^{2}=11 \cdot 6\right.$, $\mathrm{p}<0.001)$ 


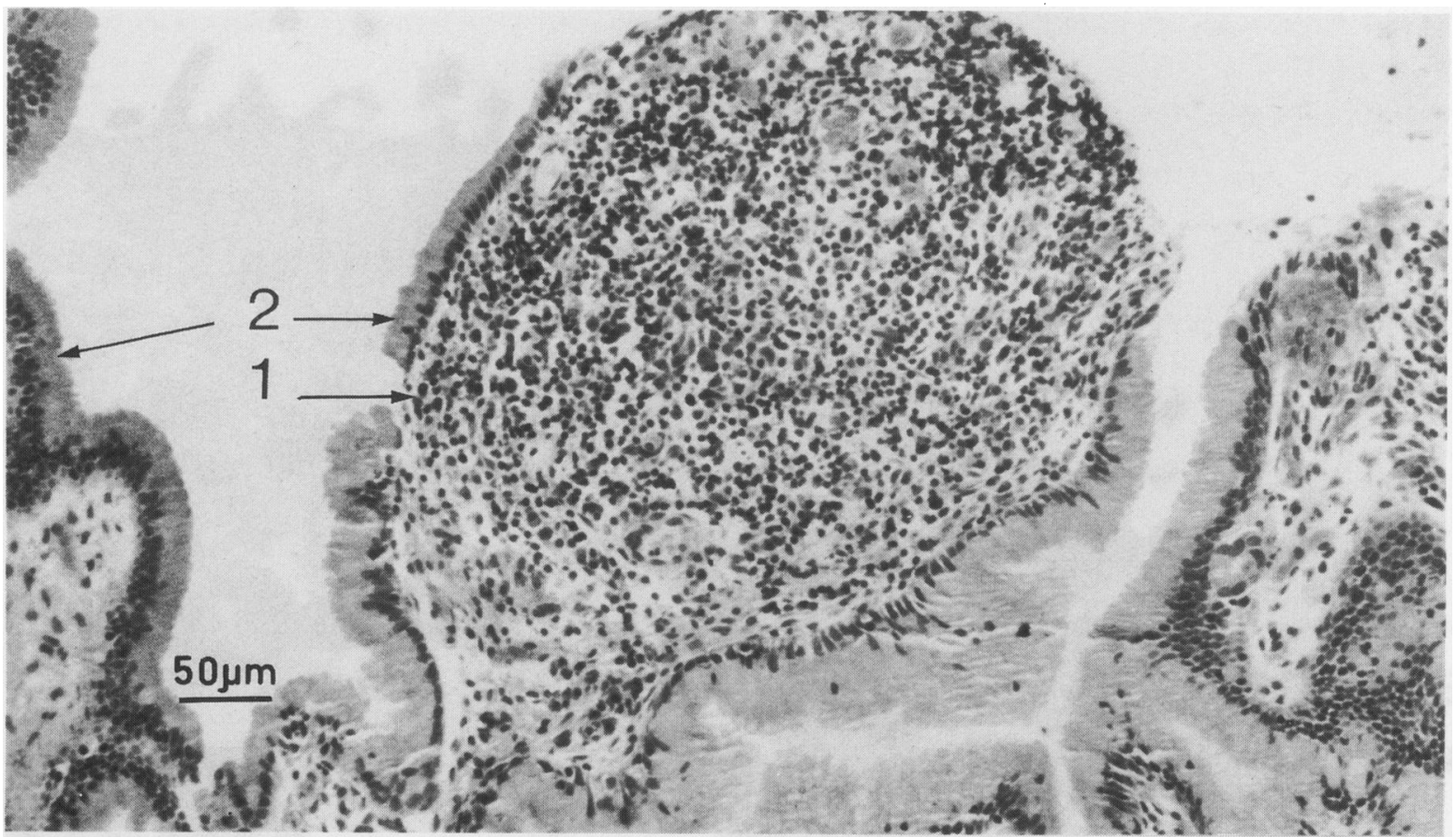

Fig 6 Focal aggregation of lymphoid cells producing pseudo follicle (without true germinal centre) (1) beneath columnar epithelium (2) of cervix yielding Chlamydia trachomatis (haematoxylin and eosin).

Table 6 shows that significantly fewer $(5 / 92,5 \%)$ specimens from patients with chlamydial cervicitis had erythema after treatment $\left(\chi^{2}=173 ; p<0.001\right)$, and it was less severe. "Follicles" had flattened and

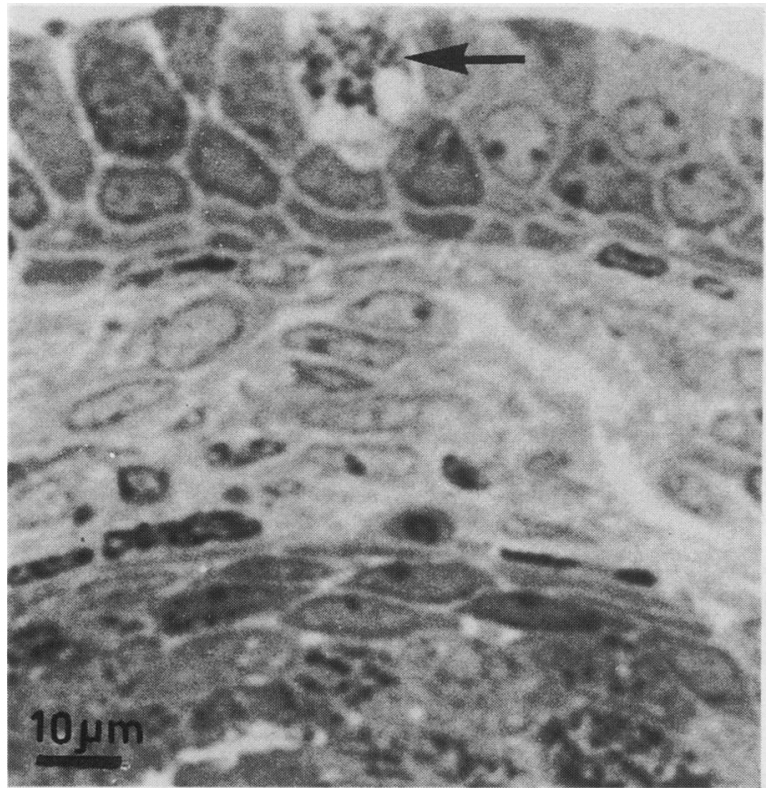

Fig 7 Inclusions (arrowed) in columnar cell from cervix yielding Chlamydia trachomatis (toluidine blue). disappeared, so they were found in only $8 / 92(9 \%)$ patients $\left(\chi^{2}=130 ; p<0.001\right)$. The cervical mucus was less purulent with an average maximum count of 41 PMNL/HPF, which was significantly less than in the untreated patients $(t=7.4, p<0.001)$. The eight control women showed no erythema or "follicles" and had an average maximum PMNL count of 60/HPF.

\section{HISTOLOGY}

Table 7 shows that lymphocytic germinal follicles (fig $5)$ were present in $5 / 165(3 \%)$ of the biopsy specimens from patients, none of the controls, and none of the follow up specimens (non-significant differences). The common cellular finding was diffuse inflammatory change with lymphocytosis and increases in plasma cells and vascularity (fig 6). Inclusions (fig 7) were present in 6/165 specimens from patients and in none from controls or subjects at follow up (non-significant differences). Electron microscopy showed chlamydiae (fig 8) in $7 / 159$ biopsy specimens from patients at diagnosis, but not from controls or patients after treatment (non-significant differences).

Table 8 shows estimated numbers of each type of inflammatory cell and degrees of vascularity in 118 predominantly subcolumnar endocervical biopsy specimens from untreated patients, 58 of those patients after antichlamydial treatment, and 43 controls. In 34 biopsy specimens we obtained pure squamous and subsquamous ectocervical material 


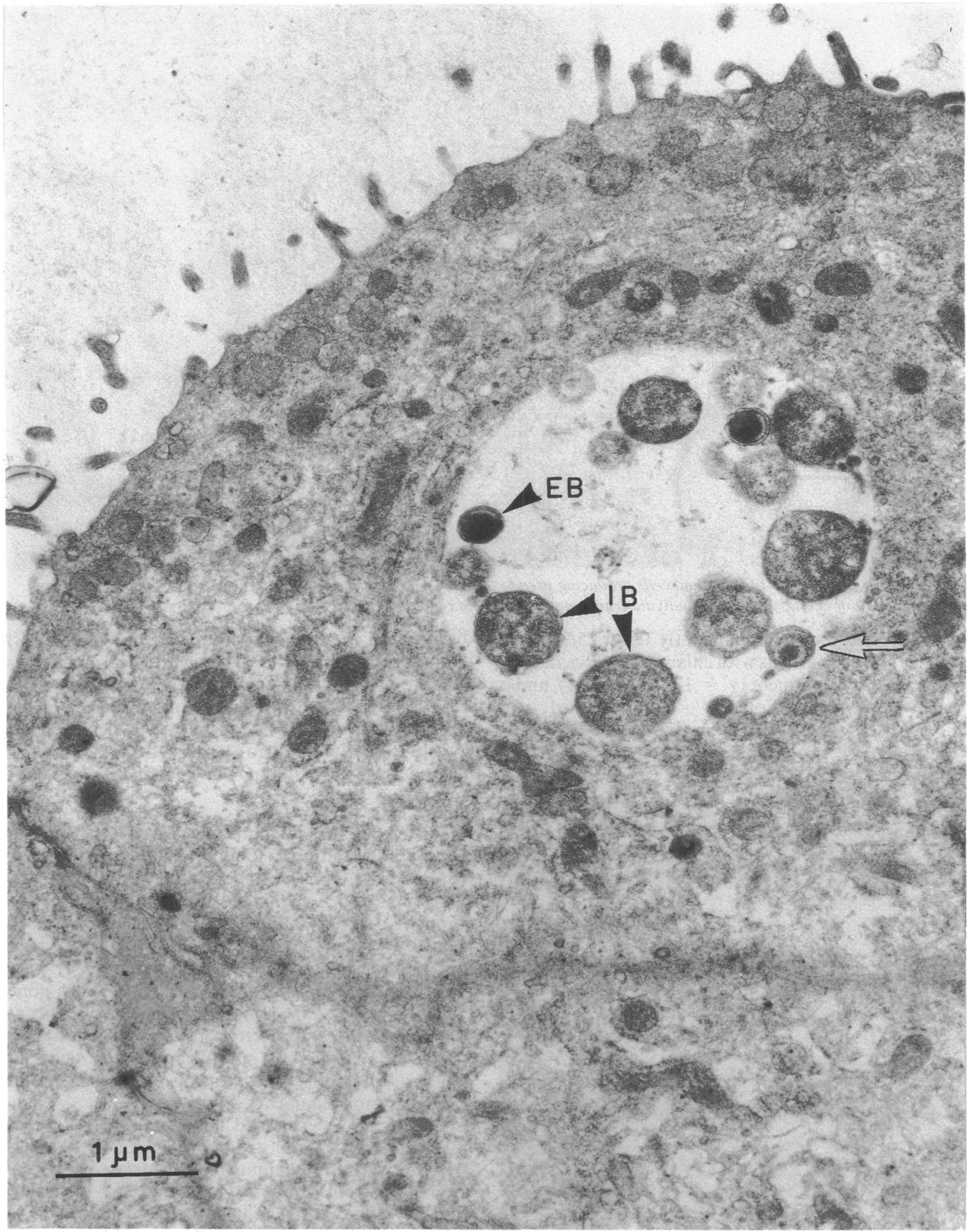

Fig 8 Electron micrograph showing initial bodies (IB) (reticular bodies) and elementary bodies (EB) in cystic space in cytoplasm of cervical columnar epithelial cell and intermediate body (white arrow) from cervix yielding Chlamydia trachomatis. 
Table 8 Findings in endocervical and ectocervical biopsy specimens (numbers of cells and degrees of vascularity measured roughly in tens on scale of $0-30$ )

\begin{tabular}{|c|c|c|c|c|c|c|}
\hline & \multicolumn{3}{|c|}{ Predominantly endocervical biopsy specimens from: } & \multicolumn{3}{|c|}{ Ectocervical biopsy specimens from: } \\
\hline & $\begin{array}{l}\text { Patients } \\
(n=118)\end{array}$ & $\begin{array}{l}\text { Controls } \\
(n=43)\end{array}$ & $\begin{array}{l}\text { Treated patients } \\
(n=58)\end{array}$ & $\begin{array}{l}\text { Patients } \\
(n=21)\end{array}$ & $\begin{array}{l}\text { Controls } \\
(n=5)\end{array}$ & $\begin{array}{l}\text { Treated patients } \\
(n=8)\end{array}$ \\
\hline $\begin{array}{l}\text { Polymorphonuclear leucocytes } \\
\text { Lymphocytes } \\
\text { Plasma cells } \\
\text { Monocytes } \\
\text { Eosinophils } \\
\text { Degrees of vascularity } \\
\text { Lymphocytic germinal follicles } \\
\text { Chlamydial inclusions }\end{array}$ & $\begin{array}{r}210(1 \cdot 8) \\
1890(16) \\
1745(14 \cdot 8) \\
160(1 \cdot 3) \\
35(0 \cdot 29) \\
1865(15 \cdot 8) \\
3(0 \cdot 03) \\
3(0.03)\end{array}$ & $\begin{array}{c}30(0 \cdot 7) \\
460(10 \cdot 7) \\
470(10 \cdot 9) \\
36(0 \cdot 7) \\
0 \\
465(10 \cdot 8) \\
0 \\
0\end{array}$ & $\begin{array}{l}45(0 \cdot 8) \\
695(12) \\
715(12 \cdot 3) \\
35(0 \cdot 6) \\
0 \\
685(12) \\
0 \\
0\end{array}$ & $\begin{array}{l}20(0 \cdot 95) \\
315(15) \\
270(12 \cdot 9) \\
15(0 \cdot 7) \\
15(0 \cdot 7) \\
310(14 \cdot 8) \\
0 \\
0\end{array}$ & $\begin{array}{l}10(2) \\
35(7) \\
30(6) \\
10(2) \\
0 \\
50(10) \\
0 \\
0\end{array}$ & $\begin{array}{l}0 \\
100(12 \cdot 5) \\
95(11 \cdot 9) \\
0 \\
0 \\
95(11 \cdot 9) \\
0 \\
0\end{array}$ \\
\hline
\end{tabular}

Table 9 Results of Ayre (Papanicolaou) smears from 161 patients and 47 extended controls

\begin{tabular}{lllll}
\hline & Results & & \\
\cline { 2 - 5 } Groups & Negative & Mild dyskaryosis & $\begin{array}{l}\text { Adenocarcinoma } \\
\text { of the cervix }\end{array}$ & Total \\
\hline Patients & $158^{*}$ & $3 \dagger$ (1 with human & 0 & 161 \\
Extended controls & 46 & 0 papillomavirus $)$ & 1 & 47 \\
Total & $204^{*}$ & $3 \dagger$ & 1 & 208 \\
\hline
\end{tabular}

*Mild dysplasia was reported in biopsy specimens from five patients whose Ayre smear results were reported as negative.

$\dagger$ Repeat smears from two patients after antichlamydial treatment showed mild dyskaryosis persisting for nine months in one, no abnormality in the other.

from 21 patients and five controls at diagnosis and eight patients after treatment. We found significantly more lymphocytes $(z=3.94, p<0.001)$ and plasma cells $(z=3.05, p<0.01)$ in subcolumnar endocervical and subsquamous ectocervical material from untreated than treated patients, but the differences between treated patients and controls were not significant for lymphocytes or plasma cells. Vascularity was greater in untreated patients than controls or treated patients, although the differences were not significant.

AYRE (PAPANICOLAOU) SMEARS

Table 9 shows the results of Ayre (Papanicolaou) smears from 161 patients and 47 extended controls. Three from patients showed mild dyskaryosis. The other 158 gave negative results, though five of those patients yielded biopsy specimens at diagnosis that showed mild dysplasia. After antichlamydial treatment the mild cellular changes had disappeared from three, but persisted in one (not a significant difference). One smear from a control subject showed adenocarcinomatous changes and the other 46 showed negative results (not a significant difference).

\section{Discussion}

The presence of erythema in $91 \%$ of patients with chlamydial cervicitis compared with $20 \%$ of controls and $5 \%$ of treated patients indicates that erythema is a sign of the infection, and probably the earliest recognisable one.

The "follicles" in $63 \%$ of patients $(81 \%$ if lumpy change is added) were nearly specific and were sensitive indicators of untreated chlamydial infection. Only treated patients had "follicles" without accompanying erythema. Because lymphocytic germinal follicles were present on histology in only five $(3 \%)$ or $10 \%{ }^{7}$ of patients with chlamydial cervicitis, the correct name for this clinical sign is the term "follicles". "Follicles" have to be differentiated from mucus blebs (fig 9) and from nabothian cysts (fig 10), both of which may be opaque or nearly transparent.

The "hypertrophic erosion" described by Rees et $a l^{18}$ is the naked eye equivalent of the colposcopic "follicles", lumps, and erythema together. It comprises congestion and oedema of the "erosion" as seen by the naked eye, and was present in $32 \%$ of patients with chlamydial cervicitis and $5 \%$ of controls in the study by Rees et al, ${ }^{18}$ compared with colposcopic "follicles" and lumps in $81 \%$ of our patients with chlamydial cervicitis and in none of our true controls. The characteristic appearances of erythema, "follicles," and lumps seen on colposcopy included some "follicles" that were in the cervical canal (fig 11) near the squamocolumnar junction in patients without ectopia.

Papillary congestion extending on the squamous side of the columnosquamous junction on colposcopy 


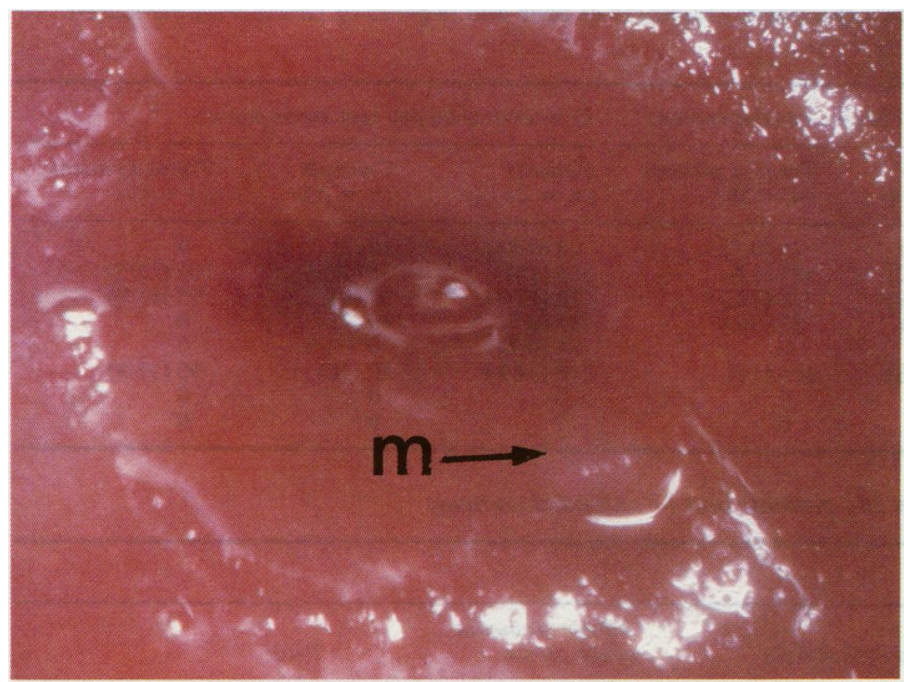

Fig 9 C trachomatis negative cervix showing mucus bleb (m) resembling a "follicle".

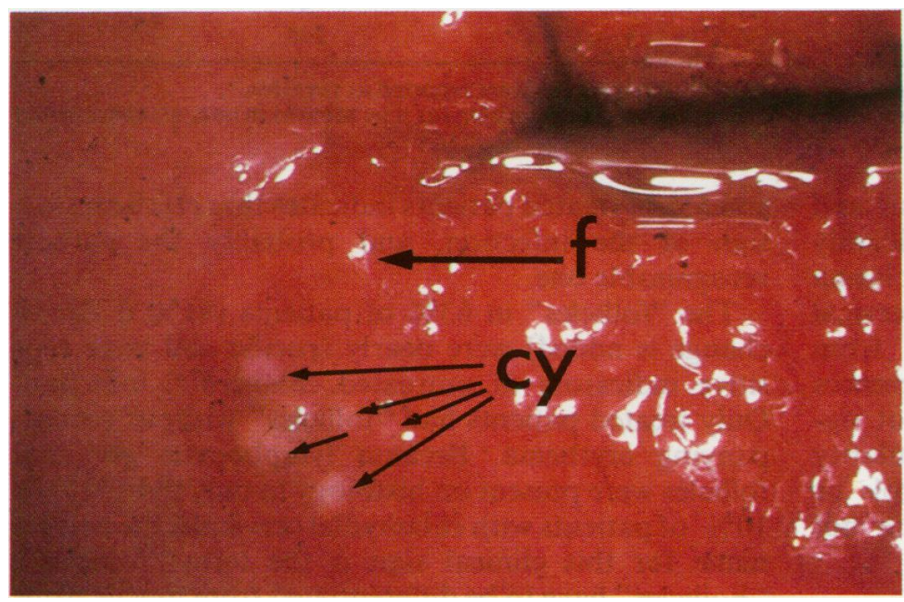

Fig 10 C trachomatis positive cervix showing erythema, "follicles" ( $f)$, and nabothian cysts (cy).

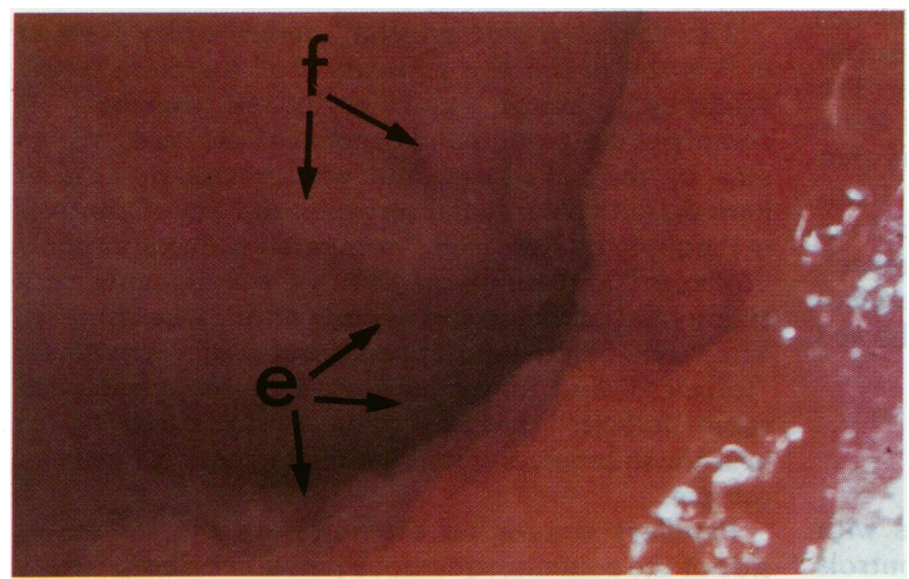

Fig 11 C trachomatis positive cervix showing erythema $(e)$ and confluent "follicles" $(f)$ within the cervical canal. 
(fig 2) suggests the spread of chlamydial infection to the ectocervix. Inflammatory changes in the subsquamous ectocervix (table 8 ) in patients with chlamydial cervicitis compared with controls support this.

The incidence of ectopia in this series was even greater in our patients with chlamydial cervicitis $(89 \%)$ than the $78 \%$ found by the naked eye by Rees $e t$ $a .^{18}$

Treatment of patients with chlamydial cervicitis reduced the incidence of erythema from $91 \%$ to $5 \%$ and the incidence of "follicles" and lumps, which were flattened and disappearing, from $81 \%$ to $9 \%$. The cervical PMNL count in patients after treatment was more than halved to near control levels.

As noted histologically, true lymphocyte germinal follicles were found in only $3 \%$ of patients with chlamydial cervicitis. The common histological change was that of diffuse infiltration by lymphocytes and plasma cells and increased vascularity. If larger specimens had been taken perhaps more lymphocyte germinal follicles would have been found, but the clinical "follicles" seen were selectively removed under colposcopic view.

The finding of inclusions in only $6 / 165(4 \%)$ biopsy specimens and electron microscopy, which gave positive results in only $7 / 159(4 \%)$ patients, showed that they were insensitive tests.

Estimations of numbers of cells showed more lymphocytes and plasma cells and there was greater vascularity in patients than controls. The difference was roughly halved after treatment. Similar changes occurred in subsquamous ectocervical tissue, which suggested that chlamydial infection extends beyond the area lined by columnar cells.

Some evidence existed of an association between chlamydiae and mild dyskaryosis. This change disappeared after antichlamydial treatment in three of four patients. The one case of cervical adenocarcinoma occurred in a control subject whose husband had recurrent genital warts.

We thank Charles Pfizer Ltd for funding the colour reproductions, our colleagues at Moorfields Eye Hospital and The London Hospital who referred patients for examination, Professor Norman Ashton who carried out the early biopsies, and the department of microbiology of The London Hospital for undertaking the Ayre smears and tests for sexually transmitted diseases other than chlamydial infection.

\section{References}

1 Dunlop EMC, Harper IA, Al-Hussaini MK, et al. Relation of TRIC agent to "non-specific" genital infection. British Journal of Venereal Diseases 1966;42:77-87.

2 Dunlop EMC, Jones BR, Al-Hussaini MK. Genital infection in association with TRIC virus infection of the eye. III. Clinical and other findings. Preliminary Report. British Journal of Venereal Diseases 1964;40:33-42.

3 Dunlop EM, Freedman A, Garland JA, et al. Infection by Bedsoniae and the possibility of spurious isolation. 2. Genital infection, disease of the eye, Reiter's disease. Am J Ophthalmol 1967;63 suppl:1073-81.

4 Dunlop EM, Hare MJ, Darougar S, Jones BR, Rice NSC. Detection of Chlamydia (Bedsonia) in certain infections of man. II. Clinical study of genital tract, eye, rectum and other sites of recovery of Chlamydia. J Infect Dis 1969;120:463-70.

5 Dunlop EMC, Goldmeier D, Darougar S, Jones BR. Chlamydial infection of the genital tract in the mothers and fathers of babies suffering from ophthalmia neonatorum due to TRIC agent. In: Catterall RD, Nicol CS, eds. Sexually transmitted diseases. London: Academic Press, 1976;83-8.

6 Hare MJ, Toone E, Taylor-Robinson D, et al. Follicular cervicitis, colposcopic appearances and association with Chlamydia trachomatis. Br J Obstet Gynaecol 1981;88:174-80.

7 Paavonen J, Vesterinen E, Meyer B, Saksela E. Colposcopic and histological findings in cervical chlamydial infection. Obstet Gynecol 1982;59:712-4.

8 Dunlop EMC, Hare MJ, Darougar S, Jones BR. Chlamydial isolates from the rectum in association with chlamydial infection of the eye or genital tract. In: Nichols RL, ed. Trachoma and related disorders. Amsterdam: Excerpta Medica, 1971;507-12.

9 Dunlop EMC, Darougar S, Treharne JD, Phillips JKA. Chlamydial proctitis: clinical aspects. European Journal of Sexually Transmitted Diseases 1986;3:127-35.

10 Goldmeier D, Darougar S. Isolation of Chlamydia trachomatis from throat and rectum of homosexual men. British Journal of Venereal Diseases 1977;53:184-5.

11 Gale JL, Digiacomo RF, Kiviat MD, Wang S-P, Bowie WR. Experimental nonhuman primate urethral infection with Chlamydia trachomatis and Ureaplasma (T-Mycoplasma). In: Hobson D, Holmes KK, eds. Non-gonococcal urethritis and related infections. Washington DC: American Society for Microbiology, 1977;205-13.

12 Swanson J, Eschenbach DA, Alexander ER, Holmes KK. Light and electron microscopic study of Chlamydia trachomatis infection of the uterine cervix. J Infect Dis 1975;131:678-87.

13 Ashton N, Dunlop EMC, Darougar S. The genus Chlamydia. In: Morton RS, Harris JRW, eds. Recent advances in sexually transmitted diseases. Edinburgh: Churchill Livingstone 1975;284.

14 Schachter J, Hill EC, King EB, Coleman VR, Jones P, Meyer KF. Chlamydial infection in women with cervical dysplasia. Am J Obstet Gynecol 1975;123:753-7.

15 Paavonen J, Vesterinen E, Meyer B, et al. Genital Chlamydia trachomatis infections in patients with cervical atypia. Obstet Gynecol 1979;54:289-91.

16 Treharne JD, Darougar S, Jones BR. Modification of the microimmunofluorescence test to provide a routine serodiagnostic test for chlamydial infection. J Clin Pathol 1977;30:510-7.

17 Dunlop EMC, Goh BT, Darougar S, Woodland R. "Triple culture tests" for diagnosis of chlamydial infection. Sex Transm Dis 1985;12:68-72.

18 Rees E, Tait IA, Hobson D, Johnson FWA. Chlamydia in relation to cervical infection and pelvic inflammatory disease. In: Hobson D, Holmes KK, eds. Nongonococcal urethritis and related infections. Washington: American Society for Microbiology, 1977:67-76. 